\title{
Potato Tuber Yield, Mineral Concentration, and Quality after Calcium Fertilization
}

\author{
George H. Clough \\ Oregon State University, Hermiston Agricultural Research and Extension Center, P.O. Box 105, \\ Hermiston, OR 97838
}

Additional index words. Solanum tuberosum, gypsum, internal brown spot, IBS, hollow heart, brown center

\begin{abstract}
In a 3-year study on a fine sandy loam soil, 'Atlantic' (1989), 'Frontier' (1990-91), and 'Russet Burbank' (198991) potato (Solanum tuberosum $\mathbf{L}$.) response to rate and time of Ca fertilization was evaluated. Calcium was applied preplant at $0,90,180$, and $270 \mathrm{~kg} \cdot \mathrm{ha}^{-1}$ as $\mathrm{CaSO}_{4}$ and side-dressed at 0,34 , and $68 \mathrm{~kg} \cdot \mathrm{ha}^{-1}$ as $\mathrm{Ca}\left(\mathrm{NO}_{3}\right)_{2}$, with treatments combined in a complete factorial. Preplant Ca fertilization increased soil Ca concentration each year. Calcium fertilization did not affect tuber yield or grade distribution. Tuber concentrations of $\mathbf{P}$, $K$, and Ca in 'Russet Burbank', Ca in 'Frontier', and $S$ in all cultivars increased with increasing preplant Ca rate. 'Russet Burbank' tuber $P, K, C a$, and Cu concentrations and 'Frontier' tuber $S$ concentration increased as side-dressed Ca rate increased. Tuber concentrations of most nutrients decreased between midseason and harvest. The incidence of internal brown spot (IBS) was very low in 'Atlantic' and 'Russet Burbank' tubers and was reduced in 'Atlantic' by preplant Ca application. In 1990, IBS severity and incidence in 'Frontier' were reduced by preplant and side-dressed Ca fertilization. In 1991, after 4 months of storage at 7C, severity and percentage of tubers with IBS were reduced by preplant and side-dressed Ca fertilization. During storage, IBS decreased in 'Russet Burbank'. Brown center in 'Russet Burbank' decreased as side-dressed Ca rate increased. In 1990, 'Russet Burbank' french-fry color improved as preplant Ca rate increased.
\end{abstract}

Poor quality due to internal defects such as brown center, internal brown spot (IBS), and hollow heart can substantially reduce the value of processing potatoes. Recently, potato production in the Pacific Northwest has been seriously affected by IBS, which is characterized by specks of fibrous or corky reddish-brown tissue interior to the vascular bundle (Wolcott and Ellis, 1956). This defect reduces tuber quality, resulting in economic loss to growers and processors. The severity of the disorder varies, depending on year and location.

IBS has been associated with localized Ca deficiencies in the tuber (Collier et al., 1980; Tzeng et al., 1986). Tuber Ca concentration may be increased through fertilization. In greenhouse pot experiments, Collier et al. (1978) demonstrated that Ca application can increase tuber $\mathrm{Ca}$ concentration and reduce IBS. Up to $40 \%$ of tuber Ca may be absorbed directly from the soil solution through the periderm (Davies and Millard, 1985). Kratzke and Palta (1985) reported evidence of functional roots on the tuber and stolon, and, in divided-pot experiments, found that tuber $\mathrm{Ca}$ concentration increased if $\mathrm{Ca}$ was applied directly to the tuber-stolon area (Kratzke and Palta, 1986). Simmons et al. (1988) demonstrated that preplant strip application of gypsum in the field with side-dressed $\mathrm{Ca}\left(\mathrm{NO}_{3}\right)_{2}$ fertilization improved grade and size and increased tuber periderm $\mathrm{Ca}$ concentrations on low-Ca, sandy soils. Locascio et al. (1992) also reported that yield per grade response to $\mathrm{Ca}$ was not obtained unless soil $\mathrm{Ca}$ levels and soil cation-exchange capacity was very low. Silva et al. (1991) obtained partial and inconsistent reduction in IBS of 'Atlantic' in response to preplant gypsum application.

This study was conducted to determine 1) if preplant and side-dressed $\mathrm{Ca}$ application can improve tuber quality on an irrigated sandy soil with moderate soil $\mathrm{Ca}$ content and 2) the influence of supplemental $\mathrm{Ca}$ application on tuber mineral concentration.

Received for publication 29 Oct. 1992. Accepted for publication 5 Aug. 1993. The cost of publishing this paper was defrayed in part by the payment of page charges. Under postal regulations, this paper therefore must be hereby marked advertisement solely to indicate this fact.

\section{Methods and Materials}

Field plots with four 7-m-long rows $0.9 \mathrm{~m}$ apart were established at Hermiston, Ore., on Adkins fine sandy loam (coarse-loamy, mixed mesic Xerollic Camborthid, $\mathrm{pH}$ 6.7, 0.9\% organic matter, $\mathrm{Ca}$ at $5.7 \mathrm{meq} / 100 \mathrm{~g}$ ). Preplant fertilizer [24.5P-140K-2.2B $\left.\left(\mathrm{kg} \cdot \mathrm{ha}^{-1}\right)\right]$ was broadcast and incorporated in March. Ethoprop was applied at $3.4 \mathrm{~kg}$ a.i./ha in a $30-\mathrm{cm}$-wide band on row centers and strip-tilled to control soil insects. Calcium as $\mathrm{CaSO}_{4}$ was applied in a $30-\mathrm{cm}$-wide band on row centers at $0,90,180$, and $270 \mathrm{~kg} \cdot \mathrm{ha}^{-}$ ${ }^{1}$ and was tilled into the bed with the remainder of the preplant fertilizer [84N-49P-47K-67S (in kg.ha ${ }^{-1}$ )] at planting. Commercial seed pieces (average weight $60 \mathrm{~g}$ ) of 'Russet Burbank' and 'Atlantic' (1989) and 'Russet Burbank' and 'Frontier' (1990-91) were planted $10 \mathrm{~cm}$ deep, $23 \mathrm{~cm}$ apart in late April each year. Two weeks later, pendemethalin and metolachlor were applied at 1.7 and $2.2 \mathrm{~kg} \cdot \mathrm{ha}^{-1}$, respectively, for weed control. Seven weeks after planting, side-dressed $\mathrm{Ca}$, as $\mathrm{Ca}\left(\mathrm{NO}_{3}\right)_{2}$ was applied to the bed tops at 0,34 , and $68 \mathrm{~kg} \cdot \mathrm{ha}^{-1} ; \mathrm{NH}_{4} \mathrm{NO}_{3}$ was applied at 76 and $152 \mathrm{~kg} \cdot \mathrm{ha}^{-}$ ${ }^{1}$ to the 34 and $0 \mathrm{~kg} \cdot \mathrm{ha}^{-1} \mathrm{Ca}$ treatment plots, respectively, to maintain equal $\mathrm{N}$ application for all plots. This fertilizer was incorporated with $7.5 \mathrm{~mm}$ of water applied by overhead sprinkler irrigation. Additional $\mathrm{N}\left(246 \mathrm{~kg} \cdot \mathrm{ha}^{-1}\right)$ was applied as $\mathrm{NH}_{4} \mathrm{NO}_{3} \cdot \mathrm{CO}\left(\mathrm{NH}_{2}\right)_{2}$ in the irrigation water in weekly increments for 8 weeks beginning 8 weeks after planting. Irrigation application averaged $700 \mathrm{~mm}$ each year. Recommended commercial practices were followed for pest control. Preplant and side-dressed fertilizer treatments were combined in a complete factorial design with four replications.

Soil was sampled midseason ( 9 weeks after planting) and at harvest to a depth of $30 \mathrm{~cm}$ from the center of the interior two beds and analyzed for $\mathrm{pH}, \mathrm{P}, \mathrm{K}, \mathrm{Ca}$, and $\mathrm{Mg}$ (Horneck et al., 1989).

Midseason and at harvest, 20 tubers/plot were cut longitudinally and evaluated visually for internal quality. Acropetal (bud), center, and basipetal (stem) tuber segments were rated for IBS severity (scale of 1 to $5,1=0 \%, 5 \geq 20 \%$ of surface area discolored) and for presence of brown center and hollow heart. Pith (medulla) tissue of 10 tubers/plot was combined and prepared 
according to Lockman (1980) for analysis for $\mathrm{Ca}$ and other mineral concentrations by a gas plasma analyzer (ICAP-9000; Jarrell-Ash, Waltham, Mass.).

At harvest, tubers were graded by size and specific gravity was determined. Tubers were placed in a commercial storage at $7 \mathrm{C}$ for 4 months, then reevaluated to determine the influence of the treatments on french-fry color (Iritani, 1974) and IBS.

Data were analyzed using general linear model procedures, with effects partitioned into single degree of freedom orthogonal contrasts (SAS Institute, 1988).

\section{Results and Discussion}

Yield. Potato yield, size distribution, and grade were not significantly affected by $\mathrm{Ca}$ treatments with any cultivar tested in any year (data not shown). Simmons and Kelling (1987) evaluated potato response to preplant and side-dressed $\mathrm{Ca}$ application on several soil types and reported little or no grade-yield improvements with 'Russet Burbank' on soils with Ca at $>3.8 \mathrm{meq} / 100 \mathrm{~g}$. Locascio et al. (1992) obtained a yield increase in 1 of 3 years (initial soil $\mathrm{Ca}$ at $2.9 \mathrm{meq} / 100 \mathrm{~g}$ ) as preplant $\mathrm{Ca}$ rate increased from 0 to $450 \mathrm{~kg} \cdot \mathrm{ha}^{-1}$; but no further response was obtained at 900 $\mathrm{kg} \cdot \mathrm{ha}^{-1}$, or in other years (initial soil $\mathrm{Ca} 4.3$ and $2.2 \mathrm{meq} / 100 \mathrm{~g}$ ). Since preplant soil Ca averaged $5.7 \mathrm{meq} / 100 \mathrm{~g}$ in my study, lack of yield/grade response was expected.

Tuber quality. Specific gravity, which averaged 1.085 for 'Atlantic', 1.073 for 'Russet Burbank', and 1.075 for 'Frontier', was not influenced by $\mathrm{Ca}$ application in any year. Similar findings were reported by Locascio et al. (1992) for 'Atlantic', 'La Chipper', and 'Superior', and by Silva et al. (1991) for 'Atlantic'.

Nine weeks after planting, tubers were small (4 to $7 \mathrm{~cm}$ in diameter) and contained very few internal defects. Wolcott and Ellis (1956) reported that small young tubers were less susceptible to IBS and that symptoms developed during periods of rapid tuber enlargement.

At harvest, average IBS severity was low, with ratings of 1.03, 1.05 , and 1.09 in the stem end, center, and bud end of the tuber, respectively. Severity differed among cultivars, averaging 1.01,

Table 1. Incidence of internal brown spot (IBS), hollow heart (HH), and brown center (BC) of 'Russet Burbank' potato as affected by side-dressed $\mathrm{Ca}$ fertilization, production year, and storage.

\begin{tabular}{lccc}
\hline \hline & \multicolumn{3}{c}{ Incidence $^{\mathrm{z}}(\%)$} \\
\cline { 2 - 4 } Treatment & IBS & HH & BC \\
\hline Side-dressed Ca $\left(\mathrm{kg} \cdot \mathrm{ha}^{-1}\right)$ & 2.22 & 1.72 & 2.96 \\
0 & 2.67 & 1.72 & 2.84 \\
34 & 2.24 & 1.54 & 1.66 \\
68 & $\mathrm{NS}$ & $\mathrm{NS}$ & $\mathrm{L}^{*}$ \\
& & & \\
Year & 4.05 & 0.96 & 2.61 \\
1989 & 0.83 & 3.07 & 3.70 \\
1990 & 2.24 & 0.94 & 1.15 \\
1991 & $* * * *$ & $* * * *$ & $* * *$ \\
& & & \\
Sampling time $(\mathrm{ST})$ & 2.81 & 2.01 & 3.82 \\
Harvest & 1.94 & 1.30 & 1.15 \\
Poststorage & $* *$ & NS & $* * * *$ \\
& $\mathrm{NS}$ & $*$ & $* * *$ \\
ST $\times$ year & & &
\end{tabular}

zPercentage of 20 tubers/plot.

Ns,*,**,***,***** Nonsignificant or significant at $P \leq 0.05,0.01,0.001$, or 0.0001 , respectively; $\mathrm{L}=$ linear.
1.05, and 1.11 for 'Russet Burbank', 'Atlantic', and 'Frontier', respectively.

In the year 'Atlantic' tubers were tested, IBS severity in the bud end was reduced significantly $(P \leq 0.05)$ by side-dressed $\mathrm{Ca}$ application compared to the control (data not shown). The percentage of tubers with IBS in the bud end and with IBS decreased linearly $(P \leq 0.05)$ from $6.25 \%$ to $3.33 \%$ and $7.42 \%$ to $3.75 \%$, respectively, as preplant Ca rate increased from 0 to $270 \mathrm{~kg} \cdot \mathrm{ha}^{-1}$. Neither hollow heart nor brown center were affected by $\mathrm{Ca}$ treatments. The percentage of tubers with IBS and with brown center was lower after storage than at harvest. In a 3-year study, Silva et al. (1991) reported inconsistent IBS reduction in 'Atlantic' in response to gypsum at 560,840 , and $840 \mathrm{~kg} \cdot \mathrm{ha}^{-1}$, with corresponding preplant soil Ca values of 4.7, 4.5, and $2.7 \mathrm{meq} / 100 \mathrm{~g}$. However, hollow heart was not influenced by gypsum treatment.

In 'Russet Burbank', the incidence and severity of IBS, hollow heart, and brown center varied by year. The percentage of tubers with brown center decreased linearly as side-dressed $\mathrm{Ca}$ rate increased (Table 1). Year and Ca side-dressed rate interacted to affect stem-end IBS severity. In 1989, stem-end IBS was more severe with Ca at 34 than with 0 or $68 \mathrm{~kg} \cdot \mathrm{ha}^{-1}$; in 1990 and 1991, values were similar with all three Ca rates (data not shown). The bud-end and average IBS severity ratings and percentage of tubers with IBS and brown center decreased during storage. Evaluation time and year interacted to affect the percentage of tubers with hollow heart and brown center; hollow heart incidence decreased in storage only in 1990, while brown center incidence decreased in 1989 and 1990. There was no effect of storage on hollow heart in 1989 or 1991 or on brown center in 1991. Tuber french-fry color, evaluated after storage, improved at a decreasing rate (quadratic $P$ $=0.04$ ) as preplant Ca rate increased (data not shown).

Table 2. Internal brown spot (IBS) of 'Frontier' potato as affected by preplant and side-dressed $\mathrm{Ca}$ fertilization, production year, and storage.

\begin{tabular}{|c|c|c|c|c|}
\hline \multirow[b]{2}{*}{ Treatment } & \multicolumn{3}{|c|}{$\mathrm{IBS}^{\mathrm{z}}$ location (\%) } & \multirow{2}{*}{$\begin{array}{c}\text { Tubers } \\
\text { affected } \\
(\%)\end{array}$} \\
\hline & Stem end & Center & Bud end & \\
\hline \multicolumn{5}{|c|}{ Preplant (PP) Ca $\left(\mathrm{kg} \cdot \mathrm{ha}^{-1}\right)$} \\
\hline 0 & 3.96 & 9.79 & 15.6 & 16.7 \\
\hline 90 & 4.27 & 8.02 & 10.8 & 13.2 \\
\hline 180 & 3.96 & 8.02 & 11.9 & 13.6 \\
\hline \multirow[t]{2}{*}{270} & 4.17 & 7.71 & 11.3 & 13.8 \\
\hline & NS & $*$ & $\mathrm{~L}^{*}$ & $*$ \\
\hline \multicolumn{5}{|c|}{ Side-dressed (SD) Ca $\left(\mathrm{kg} \cdot \mathrm{ha}^{-1}\right)$} \\
\hline 0 & 4.38 & 8.59 & 14.2 & 15.8 \\
\hline 34 & 3.91 & 8.75 & 12.9 & 15.2 \\
\hline \multirow[t]{2}{*}{68} & 3.98 & 7.81 & 10.1 & 12.0 \\
\hline & NS & NS & $\mathrm{L}^{* *}$ & $\mathrm{~L}^{*}$ \\
\hline \multicolumn{5}{|l|}{ Year } \\
\hline 1990 & 6.88 & 15.5 & 23.2 & 20.1 \\
\hline \multirow[t]{2}{*}{1991} & 1.30 & 1.3 & 1.6 & 2.6 \\
\hline & $* * * *$ & $* * * *$ & $* * * *$ & $* * * *$ \\
\hline Year $\times$ SD & NS & NS & $* *$ & NS \\
\hline \multicolumn{5}{|c|}{ Sampling time (ST) } \\
\hline Harvest & 4.74 & 8.80 & 12.7 & 15.5 \\
\hline \multirow[t]{2}{*}{ Poststorage } & 3.44 & 7.97 & 12.1 & 13.2 \\
\hline & NS & NS & NS & NS \\
\hline $\mathrm{ST} \times \mathrm{PP} \times$ year & NS & NS & NS & $*$ \\
\hline $\mathrm{ST} \times \mathrm{SD} \times$ year & NS & NS & NS & $*$ \\
\hline
\end{tabular}

zPercentage of 20 tubers/plot. Ns, ${ }^{*}, * * * * * *$ Nonsignificant or significant at $P \leq 0.05,0.01$, or 0.0001 , respectively; $\mathrm{L}=$ linear. 
In 'Frontier', which had more IBS than the other cultivars, average IBS severity (data not shown) and percentage of tubers with IBS in the center and the percentage with IBS were lower (Table 2) with preplant $\mathrm{Ca}$ than without. The percentage of tubers with IBS in the bud end decreased linearly as preplant $\mathrm{Ca}$ rate increased. The incidence and severity of IBS were more severe in 1990 than in 1991, but year and side-dressed Ca rate interacted to influence the percentage of tubers with IBS in the bud end. In 1990, IBS incidence decreased linearly as side-dressed rate increased; in 1991, rate did not affect IBS incidence, which was low (Table 3). The severity of IBS in the bud end and percentage of tubers with IBS were influenced by interactions of preplant and side-dressed rates with year and time of evaluation (data not shown). In 1990, there were no differences between ratings at harvest and after storage; bud-end IBS severity and percentage of tubers with IBS were lower with preplant $\mathrm{Ca}$ fertilization than without $(P \leq 0.05)$ and decreased linearly $(P \leq 0.05)$ as side-dressed Ca rate increased. At harvest in 1991, bud-end IBS severity and percentage of tubers with IBS were not affected by $\mathrm{Ca}$ fertilization. After storage, severity and percentage of tubers affected were lower with preplant $\mathrm{Ca}$ fertilization than without $(P \leq 0.01)$, and decreased linearly as side-dressed $C$ a rate increased $(P \leq 0.05)$. Hollow heart was not found in 'Frontier', and the incidence of brown center was

Table 3. 'Frontier' potato tuber bud-end internal brown spot (IBS) as affected by interaction of side-dressed Ca rate and year.

\begin{tabular}{lcc}
\hline \hline $\begin{array}{l}\text { Side-dressed Ca } \\
\left(\mathrm{kg} \cdot \mathrm{ha}^{-1}\right)\end{array}$ & \multicolumn{2}{c}{ Year } \\
\cline { 2 - 3 } 0 & $I B S^{z}(\%)$ & 1991 \\
\hline \multirow{3}{*}{6} & 27.2 & 1.25 \\
68 & 23.9 & 1.88 \\
& 18.6 & 1.56 \\
& $\mathrm{~L}^{* *}$ & $\mathrm{NS}$ \\
\hline
\end{tabular}

${ }^{\text {Percentage of } 640 \text { tubers/treatment. }}$

Ns, ** Nonsignificant or significant at $P \leq 0.01$, respectively; $\mathrm{L}=$ linear. too low for statistical analysis.

Ellison and Jacob (1952) reported that IBS in 'Green Mountain' and 'Katahdin' either remained the same or decreased in storage at $4 \mathrm{C}$, depending on irrigation, planting, and harvest dates. Tzeng et al. (1986) reported increased IBS incidence of 'Russet Burbank' after tuber storage at 5 to $8 \mathrm{C}$ for 5 months or $22 \mathrm{C}$ for 3 weeks. Iritani et al. (1984), however, found a higher IBS incidence in large 'Russet Burbank' tubers stored at 8.9 than at 5.6C. The increased IBS reported by Tzeng et al. (1986) may have resulted from high temperature storage $(22 \mathrm{C})$ before evaluation.

Tuber mineral concentration. Tuber mineral concentrations generally were highest in 'Russet Burbank', followed by 'Frontier', and least in 'Atlantic'.

With increasing rate of side-dressed Ca application, mid-season $\mathrm{S}$ concentration in 'Atlantic' tubers increased linearly $(P \leq 0.01)$ from $0.159 \%$ to $0.173 \%$. Tuber $\mathrm{S}$ increased linearly $(P \leq 0.001)$ from $0.173 \%$ to $0.184 \%$ with increased preplant $\mathrm{CaSO}_{4}$ rate. Tuber Ca concentration was $0.009 \%$ with side-dressed $\mathrm{Ca}$ and $0.013 \%$ without $(P \leq 0.01)$. Calcium fertilization did not affect tuber $\mathrm{P}, \mathrm{K}$, $\mathrm{Mg}, \mathrm{Mn}, \mathrm{Fe}, \mathrm{Cu}, \mathrm{B}$, or $\mathrm{Zn}$ concentrations. In the 2 years that 'Atlantic' was included in the potato Ca fertility studies by Locascio et al. (1992), medulla Ca and K concentrations were not affected by preplant $\mathrm{Ca}$ application rates up to $900 \mathrm{~kg} \cdot \mathrm{ha}^{-1}$. In this study, tuber concentrations of $\mathrm{P}, \mathrm{K}, \mathrm{Fe}, \mathrm{Cu}, \mathrm{B}$, and $\mathrm{Zn}$ decreased from midseason to harvest, likely due to dilution associated with growth. Concentrations of S and Ca increased, perhaps in response to slow mineralization of the spring-applied gypsum. In 1989, soil $\mathrm{Ca}$ at harvest increased linearly $(P \leq 0.001)$ from 4.9 to $5.5 \mathrm{meq} /$ $100 \mathrm{~g}$ as preplant $\mathrm{Ca}$ application rate increased; soil $\mathrm{S}$ was not measured.

Year interacted with Ca fertilization to affect 'Russet Burbank' tuber $\mathrm{P}$ concentration (data not shown). In 1989, tuber $\mathrm{P}$ increased from $0.456 \%$ with $0 \mathrm{~kg} \mathrm{Ca} / \mathrm{ha}$ to $0.511 \%$ with $180 \mathrm{~kg} \mathrm{Ca} / \mathrm{ha}$, then deceased to $0.478 \%$ with $270 \mathrm{~kg} \mathrm{Ca} /$ ha applied preplant (quadratic, $P \leq 0.05)$. Also in 1989, 'Russet Burbank' tuber P concentration increased linearly $(P \leq 0.05)$ from $0.464 \%$ to $0.491 \%$ as side-dressed

Table 4. Tuber (medulla) mineral concentrations of 'Russet Burbank' potato as affected by preplant and side-dressed Ca fertilization, year, and sampling time.

\begin{tabular}{|c|c|c|c|c|c|c|c|c|c|c|}
\hline \multirow[b]{2}{*}{ Treatment } & \multicolumn{5}{|c|}{ Concn (\% dry wt) } & \multicolumn{5}{|c|}{ Concn $\left(\mathrm{mg} \cdot \mathrm{kg}^{-1}\right.$ dry wt) } \\
\hline & $\mathrm{P}$ & $\mathrm{K}$ & $\mathrm{S}$ & $\mathrm{Ca}$ & $\mathrm{Mg}$ & $\mathrm{Mn}$ & $\mathrm{Fe}$ & $\mathrm{Cu}$ & $\mathrm{B}$ & $\mathrm{Zn}$ \\
\hline \multicolumn{11}{|c|}{$\overline{\text { Preplant } \mathrm{Ca}\left(\mathrm{kg} \cdot \mathrm{ha}^{-1}\right)}$} \\
\hline 0 & 0.412 & 2.58 & 0.192 & 0.032 & 0.121 & 12.1 & 84.9 & 6.3 & 12.9 & 18.6 \\
\hline 90 & 0.419 & 2.66 & 0.203 & 0.032 & 0.124 & 12.6 & 87.3 & 6.4 & 13.6 & 19.3 \\
\hline 180 & 0.423 & 2.65 & 0.206 & 0.032 & 0.122 & 12.7 & 84.9 & 6.4 & 12.6 & 18.9 \\
\hline \multirow[t]{2}{*}{270} & 0.423 & 2.68 & 0.207 & 0.035 & 0.123 & 12.6 & 82.0 & 6.6 & 13.1 & 19.5 \\
\hline & NS & $\mathrm{L}^{* *}$ & $\mathrm{~L}^{* * * * *}$ & NS & NS & $*$ & NS & NS & NS & NS \\
\hline \multicolumn{11}{|c|}{ Side-dressed Ca $\left(\mathrm{kg} \cdot \mathrm{ha}^{-1}\right)$} \\
\hline 0 & 0.418 & 2.61 & 0.204 & 0.032 & 0.122 & 12.7 & 90.7 & 6.2 & 12.5 & 18.7 \\
\hline 34 & 0.418 & 2.63 & 0.199 & 0.034 & 0.122 & 12.3 & 80.3 & 6.3 & 13.0 & 19.0 \\
\hline \multirow[t]{2}{*}{68} & 0.423 & 2.68 & 0.202 & 0.033 & 0.123 & 12.5 & 83.4 & 6.8 & 13.6 & 19.5 \\
\hline & NS & $\mathrm{L}^{*}$ & NS & NS & NS & NS & $*$ & $\mathrm{~L}^{* *}$ & NS & NS \\
\hline \multicolumn{11}{|l|}{ Year } \\
\hline 1989 & 0.478 & 2.59 & 0.172 & 0.028 & 0.107 & 10.8 & 89.8 & 5.8 & 14.4 & 18.9 \\
\hline 1990 & 0.417 & 2.73 & 0.230 & 0.044 & 0.131 & 13.5 & 91.4 & 6.9 & 13.1 & 22.1 \\
\hline \multirow[t]{2}{*}{1991} & 0.363 & 2.61 & 0.203 & 0.027 & 0.129 & 13.1 & 73.2 & 6.6 & 11.6 & 16.2 \\
\hline & $* * * *$ & $* * * *$ & $* * * *$ & $* * * *$ & $* * * *$ & $* * * *$ & $* * * *$ & $* * * *$ & $* * * *$ & $* * *$ \\
\hline \multicolumn{11}{|c|}{ Sampling time } \\
\hline Midseason & 0.428 & 2.80 & 0.202 & 0.035 & 0.131 & 13.7 & 103 & 7.7 & 14.4 & 21.1 \\
\hline \multirow[t]{2}{*}{ Harvest } & 0.411 & 2.48 & 0.201 & 0.030 & 0.114 & 11.3 & 66.6 & 5.1 & 11.7 & 17.0 \\
\hline & $* * *$ & $* * * *$ & NS & $* * * *$ & $* * * *$ & $* * * *$ & $* * * *$ & $* * * *$ & $* * * *$ & $* * * *$ \\
\hline
\end{tabular}


Ca rate increased. In 1990 and 1991, tuber P concentration was not affected by preplant or side-dressed Ca rates. Tuber K concentration increased linearly as preplant and side-dressed $\mathrm{Ca}$ rates increased (Table 4). Tuber $\mathrm{S}$ concentration increased at a decreasing rate with increasing preplant gypsum application (quadratic at $P=0.02$ ). Tuber $\mathrm{Ca}$ concentration was affected by an interaction between year and preplant and side-dressed application rates. In 1989, with no preplant $\mathrm{Ca}$, tuber $\mathrm{Ca}$ increased linearly from $0.023 \%$ to $0.030 \%$ with increasing side-dressed Ca rate (Table 5). With preplant $\mathrm{Ca}$ fertilization at any rate, tuber $\mathrm{Ca}$ concentration was unaffected by side-dressed $\mathrm{Ca}$ application, and averaged $0.026 \%$. At $0 \mathrm{~kg} \cdot \mathrm{ha}^{-1}$ side-dressed, tuber Ca increased linearly with an increasing preplant $\mathrm{Ca}$ rate $(P \leq 0.05)$; however, with side-dressed $\mathrm{Ca}$ at either rate, there was no response to preplant $\mathrm{Ca}$ fertilization. In 1990, tuber Ca concentration was unaffected by Ca fertilization (averaged $0.040 \%$ ), but, in 1991, tuber Ca concentration increased linearly $(P \leq 0.001)$ from $0.023 \%$ to $0.027 \%$ as preplant Ca rate increased. Tuber Mn concentration was higher with preplant $\mathrm{Ca}$ fertilization applied at any rate than without (Table 4). As side-dressed $\mathrm{Ca}$ rate increased, tuber $\mathrm{Cu}$ concentration increased linearly; however, Fe was reduced from 90.7 to $81.8 \mathrm{mg} \cdot \mathrm{kg}^{-1}$ by side-dressed $\mathrm{Ca}$ at either rate. Calcium fertilization did not affect

Table 5. Tuber Ca concentration of 'Russet Burbank' potato as affected by interaction of preplant and side-dressed Ca rate, 1989.

\begin{tabular}{lccc}
\hline \hline $\begin{array}{l}\text { Preplant Ca } \\
\left(\mathrm{kg} \cdot \mathrm{ha}^{-1}\right)\end{array}$ & \multicolumn{3}{c}{ Side-dressed Ca $\left(\mathrm{kg} \cdot \mathrm{ha}^{-1}\right)$} \\
\cline { 2 - 4 } & 0 & 34 & 68 \\
0 & Concn (\% dry wt) \\
90 & 0.023 & 0.028 & $0.030^{\mathrm{L} *}$ \\
180 & 0.025 & 0.033 & $0.030^{\mathrm{NS}}$ \\
270 & 0.030 & 0.024 & $0.019^{\mathrm{NS}}$ \\
& 0.031 & 0.021 & $0.023^{\mathrm{NS}}$ \\
& $\mathrm{L}^{*}$ & $\mathrm{NS}$ & $\mathrm{NS}$
\end{tabular}

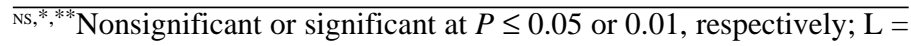
linear. concentrations of $\mathrm{Mg}, \mathrm{B}$, and $\mathrm{Zn}$. Concentrations of all minerals except $\mathrm{S}$ decreased from midseason to harvest.

'Frontier' tuber S and Ca concentrations increased linearly with increasing preplant $\mathrm{Ca}$ rate (Table 6 ); $\mathrm{S}$ also increased linearly as side-dressed $\mathrm{Ca}$ rate increased. Other mineral element concentrations did not respond to $\mathrm{Ca}$ fertilization. Tuber $\mathrm{P}$ and $\mathrm{B}$ concentrations were higher at harvest than at mid-season; all others, except $\mathrm{Cu}$ and $\mathrm{Zn}$, decreased over the same time.

Soil. At harvest, soil Ca increased linearly $(P \leq 0.001)$ from 4.9 to $5.5 \mathrm{meq} / 100 \mathrm{~g}$ with increasing preplant $\mathrm{Ca}$ application rate in 1989. Soil $\mathrm{pH}$ increased linearly $(P=0.03)$ with an increase in rate of side-dressed $\mathrm{Ca}$ application, but the effect was slight (5.88 to 6.05). Soil $\mathrm{pH}$ increased from mid-season to harvest, while $\mathrm{P}, \mathrm{K}$, and $\mathrm{Ca}$ concentrations decreased during the same period.

In 1990, mid-season soil Ca increased linearly $(P \leq 0.05)$ from 5.2 to $5.5 \mathrm{meq} / 100 \mathrm{~g}$ as preplant $\mathrm{Ca}$ application rate increased. Soil $\mathrm{P}$ and $\mathrm{K}$ content decreased from midseason to harvest.

In 1991, midseason soil Ca concentration increased linearly $(P$ $\leq 0.05$ ) from 4.5 to $4.8 \mathrm{meq} / 100 \mathrm{~g}$ as preplant $\mathrm{Ca}$ application rate increased. Soil $\mathrm{pH}$ increased linearly $(P \leq 0.01)$ from 6.11 to 6.27 as side-dressed $\mathrm{Ca}$ rate increased. Soil $\mathrm{P}$ and $\mathrm{K}$ decreased from midseason to harvest, but $\mathrm{Ca}$ and $\mathrm{Mg}$ concentrations were similar at each sampling time. Locascio et al., (1992) reported a linear increase in soil $\mathrm{Ca}$ at harvest as preplant $\mathrm{Ca}$ rate increased from 0 to $900 \mathrm{~kg} \cdot \mathrm{ha}^{-1}$.

The results of this study have shown that potato quality may be improved by supplemental Ca fertilization. With an IBS-susceptible cultivar such as 'Frontier', preplant and side-dressed Ca fertilization increased tuber $\mathrm{Ca}$ concentration and improved tuber quality. The reduced IBS incidence and severity after storage associated with preplant and side-dressed $\mathrm{Ca}$ application may be especially important for the processing industry, which relies heavily on stored tubers. However, it is unknown whether the amelioration of IBS due to supplemental Ca fertilization would result when IBS is more severe than in the 3 years of this trial. Although these data show that IBS can be reduced and other quality characteristics may

Table 6. Tuber (medulla) mineral concentrations of 'Frontier' potato as affected by preplant and side-dressed Ca fertilization, year, and time of sampling.

\begin{tabular}{|c|c|c|c|c|c|c|c|c|c|c|}
\hline \multirow[b]{2}{*}{ Treatment } & \multicolumn{5}{|c|}{ Concn (\% dry wt) } & \multicolumn{5}{|c|}{ Concn $\left(\mathrm{mg} \cdot \mathrm{kg}^{-1}\right.$ dry wt) } \\
\hline & $\mathrm{P}$ & $\mathrm{K}$ & $\mathrm{S}$ & $\mathrm{Ca}$ & $\mathrm{Mg}$ & $\mathrm{Mn}$ & $\mathrm{Fe}$ & $\mathrm{Cu}$ & $\mathrm{B}$ & $\mathrm{Zn}$ \\
\hline \multicolumn{11}{|c|}{ Preplant Ca $\left(\mathrm{kg} \cdot \mathrm{ha}^{-1}\right)$} \\
\hline 0 & 0.363 & 2.52 & 0.195 & 0.033 & 0.134 & 14.0 & 73.0 & 5.3 & 12.0 & 19.0 \\
\hline 90 & 0.357 & 2.52 & 0.196 & 0.033 & 0.134 & 14.2 & 76.6 & 5.4 & 12.0 & 18.7 \\
\hline 180 & 0.365 & 2.53 & 0.203 & 0.034 & 0.136 & 13.9 & 72.3 & 5.5 & 12.1 & 19.0 \\
\hline \multirow[t]{2}{*}{270} & 0.369 & 2.58 & 0.207 & 0.036 & 0.136 & 14.4 & 72.5 & 5.3 & 11.7 & 19.1 \\
\hline & NS & NS & $\mathrm{L}^{* * * *}$ & $\mathrm{~L}^{* *}$ & NS & NS & NS & NS & NS & NS \\
\hline \multicolumn{11}{|c|}{ Side-dressed Ca $\left(\mathrm{kg} \cdot \mathrm{ha}^{-1}\right)$} \\
\hline 0 & 0.364 & 2.60 & 0.196 & 0.034 & 0.134 & 14.2 & 75.0 & 5.6 & 11.8 & 19.0 \\
\hline 34 & 0.362 & 2.54 & 0.201 & 0.034 & 0.135 & 14.0 & 74.1 & 5.3 & 11.8 & 18.8 \\
\hline \multirow{2}{*}{68} & 0.365 & 2.54 & 0.204 & 0.034 & 0.136 & 14.3 & 71.7 & 5.3 & 12.2 & 19.0 \\
\hline & NS & NS & $\mathrm{L}^{* *}$ & NS & NS & NS & NS & NS & NS & NS \\
\hline \multicolumn{11}{|l|}{ Year } \\
\hline 1990 & 0.374 & 2.56 & 0.204 & 0.044 & 0.138 & 15.6 & 81.5 & 5.6 & 13.0 & 19.8 \\
\hline \multirow[t]{2}{*}{1991} & 0.353 & 2.51 & 0.197 & 0.024 & 0.133 & 12.7 & 65.7 & 5.2 & 10.9 & 18.1 \\
\hline & $* * * *$ & NS & $* *$ & $* * * *$ & $* * *$ & $* * * *$ & $* * * *$ & $*$ & $* * * *$ & $* * *$ \\
\hline \multicolumn{11}{|l|}{ Sampling time } \\
\hline Midseason & 0.359 & 2.57 & 0.204 & 0.037 & 0.139 & 14.9 & 82.8 & 5.5 & 11.3 & 19.2 \\
\hline \multirow[t]{2}{*}{ Harvest } & 0.368 & 2.50 & 0.196 & 0.031 & 0.131 & 13.4 & 64.4 & 5.3 & 12.5 & 18.8 \\
\hline & $*$ & $* *$ & $* * *$ & $* * * *$ & $* * * *$ & $* * *$ & $* * * *$ & NS & $* * * *$ & NS \\
\hline
\end{tabular}

$\mathrm{Ns}^{*}{ }^{* *},{ }^{* * *},{ }^{* * * *}$ Nonsignificant or significant at $P \leq 0.05,0.01,0.001$, or 0.0001 , respectively; $\mathrm{L}=$ linear. 
be improved with Ca application, IBS cannot be managed with $\mathrm{Ca}$ fertilization alone. Environmental factors associated with IBS include high temperatures and moisture stress (O'Brien and Rich, 1976). Cultural practices also can affect IBS. Potato cultivars are differentially susceptible to the disorder (Collier et al., 1980; Wolcott and Ellis, 1959). Ellison and Jacob (1952) found that IBS at harvest or after storage varied depending on irrigation, planting, and harvest dates. Iritani et al. (1984) reported that late planting and the foliar application of maleic hydrazide can reduce the incidence of IBS and that high-temperature storage increased IBS severity in large tubers.

\section{Literature Cited}

Collier, G.F., D.C.E. Wurr, and V.C. Huntington. 1978. The effect of calcium nutrition on the incidence of internal rust spot in the potato. $\mathrm{J}$. Agr. Sci. Cambridge 91:241-243.

Collier, G.F., D.C.E. Wurr, and V.C. Huntington. 1980. The susceptibility of potato varieties to internal rust spot in the potato. J. Agr. Sci. Cambridge 94:407-410.

Davies, H.V. and P. Millard. 1985. Fractionation and distribution of calcium in sprouting and non-sprouting potato tubers. Ann. Bot. 56:745754.

Ellison, J.H. and W.C. Jacob. 1952. Internal browning of potatoes as affected by date of planting and storage. Amer. Potato J. 29:241-252.

Horneck, D.A., J.M. Hart, K. Topper, and B. Koepsell. 1989. Methods of soil analysis used in the soil testing laboratory of Oregon State University. Agr. Expt. Sta. Oregon State Univ. SM89:4.

Iritani, W.M. 1974. Objective measurement of french fry color. Amer. Potato J. 51:170-173.

Iritani, W.M., L.D. Weller, and N.R. Knowles. 1984. Factors influencing incidence of internal brown spot in Russet Burbank potatoes. Amer.
Potato J. 61:335-343.

Kratzke, M.G. and J.P. Palta. 1985. Evidence for the existence of functional roots on potato tubers and stolons: Significance in water transport to the tuber. Amer. Potato J. 62:227-236.

Kratzke, M.G. and J.P. Palta. 1986. Calcium accumulation in potato tubers: Role of the basal roots. HortScience 21:1022-1024.

Locascio, S.J., J.A. Bartz, and D.P. Weingartner. 1992. Calcium and potassium fertilization of potatoes grown in north Florida. I. Effects on potato yield and tissue $\mathrm{Ca}$ and $\mathrm{K}$ concentrations. Amer. Potato J. 69:95104.

Lockman, R.B. 1980. Review of soil and plant tissue preparation procedures. J. Assn. Offic. Anal. Chemists 63:766-769.

O'Brien, M.J. and A.E. Rich. 1976. Potato diseases. U.S. Dept. Agr.-Agr. Res. Serv. Agr. Hdbk 474.

SAS Institute. 1988. SAS/STAT user's guide. release 6.03. SAS Institute, Cary, N.C.

Silva, G.H., R.W. Chase, R. Hammerschmidt, M.L. Vitosh, and R.B. Kitchen. 1991. Irrigation, nitrogen and gypsum effects on specific gravity and internal defects of Atlantic potatoes. Amer. Potato J. 68:751-765

Simmons, K.E. and K.A. Kelling. 1987. Potato responses to calcium application on several soil types. Amer. Potato J. 64:119-136.

Simmons, K.E., K.A. Kelling, R.P. Wolkowski, and A. Kelman. 1988. Effect of calcium source and application method on potato yield and cation composition. Agron. J. 80:13-21.

Tzeng, K.C., A. Kelman, K.E. Simmons, and K.A. Kelling. 1986. Relationship of calcium nutrition to internal brown spot of potato tubers and sub-apical necrosis of sprouts. Amer. Potato J. 63:87-97.

Wolcott, A.R. and N.K. Ellis. 1956. Associated forms of internal browning of potato tubers in northern Indiana. Amer. Potato J. 33:343-352.

Wolcott, A.R. and N.K. Ellis. 1959. Internal browning of potato tubers: Varietal susceptibility as related to weather and cultural practices. Amer. Potato J. 36:394-403. 